\title{
Rhizobium strains competitiveness on bean nodulation in Cerrado soils
}

\author{
Ruy Raposeiras ${ }^{(1)}$, Ivanildo Evódio Marriel(2), Maria Rita Scotti Muzzi(1), Edilson Paiva(2), \\ Israel Alexandre Pereira Filho(2), Lilia Costa Carvalhais ${ }^{(1)}$, Raul Vinícius Magalhães Passos ${ }^{(1)}$, \\ Patrícia Pereira Pinto ${ }^{(1)}$ and Nadja Maria Horta de Sá(1)
}

\begin{abstract}
(1)Universidade Federal de Minas Gerais, Instituto de Ciências Biológicas, Dep. de Botânica, Pampulha, Caixa Postal 486, CEP $31270-901$ Belo Horizonte, MG, Brazil. E-mail: rraposeiras@yahoo.com.br, mrita@icb.ufmg.br, liliacarvalhais@hotmail.com, raulvinicius@ig.com.br, nadja@icb.ufmg.br (2)Embrapa Milho e Sorgo, Caixa Postal 151, CEP 35701-970 Sete Lagoas, MG, Brazil. E-mail: imarriel@cnpms.embrapa.br, edilson@cnpms.embrapa.br, Israel@cnpms.embrapa.br
\end{abstract}

\begin{abstract}
The objective of this work was to identify the most competitive and effective Rhizobium strains in order to increase common bean yield by nitrogen fixation as alternative or complementation to the nitrogen fertilization. Competitiveness tests were lead in axenic conditions, in Cerrado soil pots and in three field experiments, with native Rhizobium strains that were previously identified, according to their effectiveness and genetic variability. The identification of strains in nodules was performed using serological tests (axenic conditions) - agglutination and enzyme linked immunosorbent (Elisa) assays - and random amplified polymorfic DNA (RAPD) (Cerrado soil). Plant yield was determined using the dry weight (greenhouse conditions), total $\mathrm{N}$ and grain yield (field experiments). Among the analyzed Rhizobium strains, native strain SLA 2.2 and commercial strain CIAT 899 were the dominant nodules in plants of the most productive plots, presenting yield productivity similar or higher to those obtained in treatments where $20 \mathrm{~kg} \mathrm{ha}^{-1}$ of $\mathrm{N}$ were applied.
\end{abstract}

Index terms: Phaseolus vulgaris, nodule occupancy, Elisa, RAPD.

\section{Capacidade competitiva de estirpes de Rhizobium na nodulação do feijoeiro em solos de Cerrado}

\begin{abstract}
Resumo - O objetivo deste trabalho foi identificar as estirpes de Rhizobium mais efetivas e competitivas, a fim de maximizar a produtividade do feijoeiro por meio da fixação de nitrogênio, como alternativa à adubação nitrogenada. Foram conduzidos testes de competitividade em condições axênicas, em vasos com solo do Cerrado e em três experimentos de campo, com estirpes de Rhizobium nativas, previamente selecionadas quanto à efetividade e à variabilidade genética. A identificação das estirpes nos nódulos foi efetuada por meio das técnicas de aglutinação e ensaio imunoabsorvente de ligação de enzimas (Elisa), em condições de casa de vegetação, e pela técnica de DNA polimórfico amplificado ao acaso (RAPD), em solo de Cerrado. A produtividade das plantas foi determinada pela produção de matéria seca, teor de N e produção de grãos (condições de campo). A estirpe nativa SLA 2.2 e a estirpe comercial CIAT 899 foram dominantes nos nódulos das plantas das parcelas mais produtivas, com índices de produtividade iguais ou superiores aos obtidos nos tratamentos em que foram aplicados $20 \mathrm{~kg} \mathrm{ha}^{-1}$ de N.
\end{abstract}

Termos para indexação: Phaseolus vulgaris, ocupação nodular, Elisa, RAPD.

\section{Introduction}

Common bean (Phaseolus vulgaris L.) is one of the most traditional crops in Brazil and very expressive in "Cerrados", an edaphic type of savanna in the central region of the country. However, yield is very low, due to poor cropping practices, such as an inefficient supply of fertilizer, especially nitrogen $(\mathrm{N})$. Biological nitrogen fixation (BNF) by rhizobia can supply partly or all
$\mathrm{N}$ required by plant legumes. Bean plants are considered very promiscuous, nodulating with various fast growing Rhizobium such as $R$. leguminosarum bv. phaseoli (Jordan, 1984), R. tropici (Martinez-Romero et al., 1991), $R$. etli (Segovia et al., 1993), R. gallicum and $R$. giardini (Amarger et al., 1997).

Tropical soils present a high number of these rhizobial strains, but they are considered of low efficiency (Pereira et al., 1991). On the other side, this population 
is very competitive, jeopardizing inoculation responses of bean with effective Rhizobium. Competitiveness in rhizobia refers to the relative ability of a given strain to infect a legume and cause nodule formation in the presence of other strains. There is competition at different levels: in rhizosphere, for survival and multiplication (Chatel et al., 1968); for accessible infection sites on roots and during penetration through the roots and nodule development, a stage presumably including several phases (Sessitsch et al., 2002).

In order to increase bean yield by $\mathrm{N}_{2}$ fixation, as alternative for nitrogenous fertilizers, it is necessary to identify the most competitive and effective strains, which requires the determination of the nodule occupancy using a suitable marker. Different methods were employed in the identification of rhizobia isolated from nodules, especially in plants cultivated in field, including antibiotic resistance (Somasegaran \& Hoben, 1985), agglutination immunology (Vincent, 1970), immunodiffusion (Somasegaran \& Hoben, 1985), immunoblot assay (Khan et al., 1999), enzyme linked immunosorbent assay (Elisa) and others based on DNA analysis (Sá et al., 1997; Handley et al., 1998).

The objective of this work was to evaluate competitiveness of efficient bean nodulating strains of Rhizobium isolated from Cerrado soils employing agglutination, Elisa and RAPD (Random amplified polymorphic DNA) methods of identification.

\section{Material and Methods}

\section{Rhizobium strains and bean plants}

The strains of Rhizobium tropici (SLBR 3.12, SLBR 2.1, FJ 2.12, SLP 3.3, SLP 4.9, SLA 2.2, SLA 3.2, CPAC $\mathrm{H}_{20}$ and $\mathrm{CPAC}_{41}$ ), R. leguminosarum bv. phaseoli (SLP 4.7), previously selected by effectiveness (Pinto et al., 1995), and commercial strains (CIAT 899 and PRF 81) were used. Phaseolus vulgaris cv. Carioca and cv. Diamante Negro were used as host plants. Rhizobial cells were grown in liquid manitol medium yeast extract (YM) at $29^{\circ} \mathrm{C}$, in shaker, for 48 hours and maintained in the same medium containing agar (YMA) at $4^{\circ} \mathrm{C}$ (Vincent, 1970). The number of cells was determined by measuring the optical density at $625 \mathrm{~nm}$ and verified by viable cell count after serial dilution on YMA.

\section{Nodule occupancy and $N_{2}$ fixation under greenhouse conditions}

Seeds of Phaseolus vulgaris (cv. Carioca) were surface-sterilized $\left(\mathrm{HgCl}_{2}, 0.1 \%\right)$ and aseptically germinated before planting in Leonard jars filled with sterilized sand and vermiculite (1:2, v/v) (Vincent, 1970). Pairs of strains in a 1:1 ratio were used as double inoculants or either single strain. The inoculum consisted of $1 \mathrm{~mL}$ from each strain $\left(10^{8}\right.$ viable cells $\left.\mathrm{mL}^{-1}\right)$, standarded at $625 \mathrm{~nm}$. Plants were watered as needed with a N-free plant nutrient solution. Controls included non-inoculated plants, without or with mineral $\mathrm{N}$ supplied as $\mathrm{KNO}_{3}\left(30 \mathrm{mg}\right.$ of $\mathrm{N}_{\text {plant }}{ }^{-1}$ week $\left.^{-1}\right)$. After 30 days, plants were harvested and nodule number and plant shoot dry weight were evaluated. Three experiments were accomplished under controlled greenhouse conditions. The nodule occupancy was determined by agglutination and Elisa assays as described below.

The best Rhizobium strains selected in vitro were used to inoculate bean seeds as above (cv. Carioca and cv. Negro Argel) planted in pots filled with Cerrado soil where different plants, including bean, have been cultivated for the last ten years. Soil with clay texture presented $\mathrm{pH}$ 5.8; $\mathrm{H}+\mathrm{Al}, 5.0$ eqm $100 \mathrm{~cm}^{-3}$; Ca, 3.4 eqm $100 \mathrm{~cm}^{-3}$; Mg, 0.79 eqm $100 \mathrm{~cm}^{-3}$; K, 259 ppm; P, 16 ppm; organic matter, $3.35 \%$. The rhizobial population in this soil was around $10^{3}$ to $10^{4}$ cells $\mathrm{g}^{-1}$ of soil, estimated according to Vincent (1970). Controls included non-inoculated plants, with or without mineral $\mathrm{N}$ supplied by $\mathrm{NH}_{4} \mathrm{SO}_{4}$ (three applications in total of 100 ppm of N). After 40 days, plants were harvested and nodules number, plant shoot dry weight and plant total $\mathrm{N}$ were evaluated as described by Tedesco (1978). The nodule occupancy was determined by agglutination, Elisa and RAPD assays as described. These experiments were performed in a randomized block design, with five replicates, and the data were submitted to analysis of variance.

\section{Field experiment}

Three experiments were performed in two sites. Site A was cultivated only with maize and sorghum in the last ten years. The soil presented: $\mathrm{pH} 6.3 ; \mathrm{H}+\mathrm{Al}$, 2.25 eqm $100 \mathrm{~cm}^{-3}$; Ca, 5.08 eqm $100 \mathrm{~cm}^{-3}$; Mg, 0.71 eqm $100 \mathrm{~cm}^{-3}$; K, 5.5 ppm; P, 5 ppm; organic matter, 2.3\%; and no rhizobial population. Site B, where different plants, including bean, were cultivated in the last ten years, presented the same characteristics described before in pot culture. 
Rhizobium strains selected in pot culture, SLA 2.2, CIAT 899 and PRF 81 from Iapar and Embrapa Cerrados were used as inoculants. The peat-based inoculants were prepared by Embrapa Cerrados at a concentration of $10^{8}$ viable cells $\mathrm{g}^{-1}$ of peat. The cv. Carioca was inoculated with pairs of strains at a 1:1 ratio as double inoculants or either single-strain. The experiments were performed in a randomized block design with five replicates, including plots that were not inoculated, with or without mineral N. In site $\mathrm{A}$, in the first experiment, $20 \mathrm{~kg} \mathrm{ha}^{-1}$ of $\mathrm{N}$ were applied and, in the second, 20, 40 and $60 \mathrm{~kg} \mathrm{ha}^{-1}$ of $\mathrm{N}$. In site B, 20, 40 and $60 \mathrm{~kg} \mathrm{ha}^{-1}$ of $\mathrm{N}$ were used. Yield was evaluated 45 days after planting by shoot dry weight, plant total N (Tedesco, 1978) and yielded grains. One sample of nodule per treatment was collected and maintained in silica for strains identification by RAPD. The data were subjected to analysis of variance.

\section{Rhizobium strains identification in competition assays}

Agglutination and Elisa assays were used for evaluating the specificity of antibodies. The agglutination reactions were accomplished in glass plates using 10 to $20 \mathrm{~mL}$ of antigen (pure culture of each strain of nodule exsudate) for $10 \mu \mathrm{L}$ of antibody per reaction. The Elisa assays were performed in polystyrene plates according to Ahmad et al. (1981), using an Elisa plates' reader (Universal Microplate Reader, ELX 800), at $405 \mathrm{~nm}$. For antibody preparation, pure cultures of the Rhizobium strains were grown in defined medium (Somasegaran \& Hoben, 1985) for four days at $24^{\circ} \mathrm{C}$. The cells were recovered by centrifugation, washed in phosphate buffered saline (PBS) and disrupted by ultra-sonication (sonifier Branson 450, output 3, out cycle 75\%) with two cycles of 30 seconds and one-minute interval. The rabbits immunization process was accomplished according to Somasegaran \& Hoben (1985). Titers for the antisera were equal or higher than 1:800 and for the analysis, a dilution to $1: 30(\mathrm{v} / \mathrm{v})$, with $0.85 \%$ of saline solution was performed. Controls included the strains isolated without antiserum.

Bacterial genomic DNA isolated from nodules from field and greenhouse experiments was extracted using the method described in Sá et al. (1997). Amplification reactions were performed with a Perkin-Elmer 9600 hermocycler, in which reactions consisted of 40 cycles, each cycle including the following steps: denaturation at $94^{\circ} \mathrm{C}$, for 15 seconds, annealing at $35^{\circ} \mathrm{C}$ for 30 seconds and polymerization at $72^{\circ} \mathrm{C}$ for one minute. An additional cycle for extension was conduced at $72^{\circ} \mathrm{C}$ for 7 minutes. Each reaction mixture of $25 \mu \mathrm{L}$ was composed of $2.5 \mathrm{mM}$ of $\mathrm{MgCl}_{2}, 10 \mathrm{mM}$ of Tris$\mathrm{HCl}, 0.01 \mathrm{mM}$ of each dNTP (dATP, dCTP, dGTP, dTTP), $1 \mathrm{U}$ of Taq DNA polymerase, $0.4 \mu \mathrm{M}$ of primer, $11 \mu \mathrm{L}$ of $\mathrm{H}_{2} \mathrm{O}$; and $25 \mathrm{ng}$ of DNA. The following five primers from Operon kit (Operon Technologies Inc.) were used: OPACO4 (ACGGGGACCTG), OPACO3 (CACTGGCCCA), OPAE10 (AGCAGCGAGG), OPAA10 (TGGTCGGGTG) and OPAE10 (CTAAGCGCA). After the reaction, the products were electrophoretically separated on 5\% polyacrylamide gels. The gels were silver stained (Santos et al., 1993) and photographed. For strain identification, the fingerprint of each original strain was compared with the fingerprinting of the isolated ones for each primer tested. The strains that showed likelihood $\geq 70 \%$ of polymorphic products were considered similar to the original strain.

\section{Results and Discussion}

Total numbers of nodules, nodule occupancy data (by agglutination and Elisa assays) and dry matter of plants inoculated with Rhizobium strains are shown in Table 1. Three experiments were accomplished under controlled greenhouse conditions. In the first one, CIAT 899, SLP 4.7, SLP 3.3 and SLBR 3.12 strains were tested. Among these strains, CIAT 899 and SLP 4.7 were the most competitive, varying from 80 to $98 \%$ of nodule occupancy index in agglutination and Elisa tests. The SLBR 3.12 was the least competitive strain. A high level of cross reactions was observed.

In the second experiment, which included CIAT 899, FJ 2.12, SLA 2.2, SLAP 4.9, SLA 3.2 and SLBR 2.1, the most competitive strains were SLA 2.2, followed by SLA 3.2. The values of nodule occupancy ranged between 60 to $100 \%$ (SLA 2.2) and 30 to 95\% (SLA 3.2). The most competitive strain, CIAT 899, in the first experiment, kept its higher competitiveness in relation to the other strains (FJ 2.12, SLP 4.9 and SLBR 2.1). The competition between FJ 2.12 and SLBR 2.1 showed high numbers of nodules without reaction and with cross reaction (80\%).

In the last experiment, $\mathrm{CPAC} \mathrm{H}_{20}$ was the most competitive, occupying $60 \%$ or more of the nodules, in both techniques. In score of higher percentage of nodule occupation, the CPAC $\mathrm{H}_{20}$ was followed by SLA 2.2 and CIAT 899. The CPAC $\mathrm{H}_{41}$ strain was the least competitive in this group. The most competitive strains 
CPAC $\mathrm{H}_{20}$, SLA 2.2 and CIAT 899 confirmed the high effectiveness when alone or when co-inoculated with other strains. The SLA 3.2 strain, despite being very competitive, showed little effectiveness in beans with low dry matter production. Although the SLP 3.3 presented low competitiveness, it was the most effective strain when inoculated alone. The nodule number parameter in experiments 1 and 3 did not show statistical differences (Duncan, 5\%). However, a higher number of nodules does not necessarily correspond to a higher yield of plant dry matter, as demonstrated by SLBR 2.1 alone or in co-inoculation with CIAT 899 strain. This fact indicates that the presence of great number of nodules not always is guarantee of effectiveness of an inoculum (Provorov et al., 1994) and that the compatibility between strains in mix inoculants is an important factor to be considered (Brown \& Ahmad, 1996).

In a pot culture, the nodule occupancy data, obtained by RAPD analysis (Figures 1 and 2), using specially OPAA10 and OPACO4 primers, showed that SLA 2.2

Table 1. Number of nodules, Rhizobium strains nodule occupancy by agglutination (A) and Elisa (E) assays and dry weight $\left(\right.$ g plant $^{-1}$ ) of bean plants under axenic greenhouse conditions, in three experiments, each consisting of strains: CIAT 899, SLP 4.7, SLP 3.3, SLBR 3.12, FJ 2.12, SLA 2.2, SLP 4.9, SLA 3.2, SLBR 2.1, CPAC $\mathrm{H}_{41}$ e CPAC $\mathrm{H}_{20}{ }^{(1)}$.

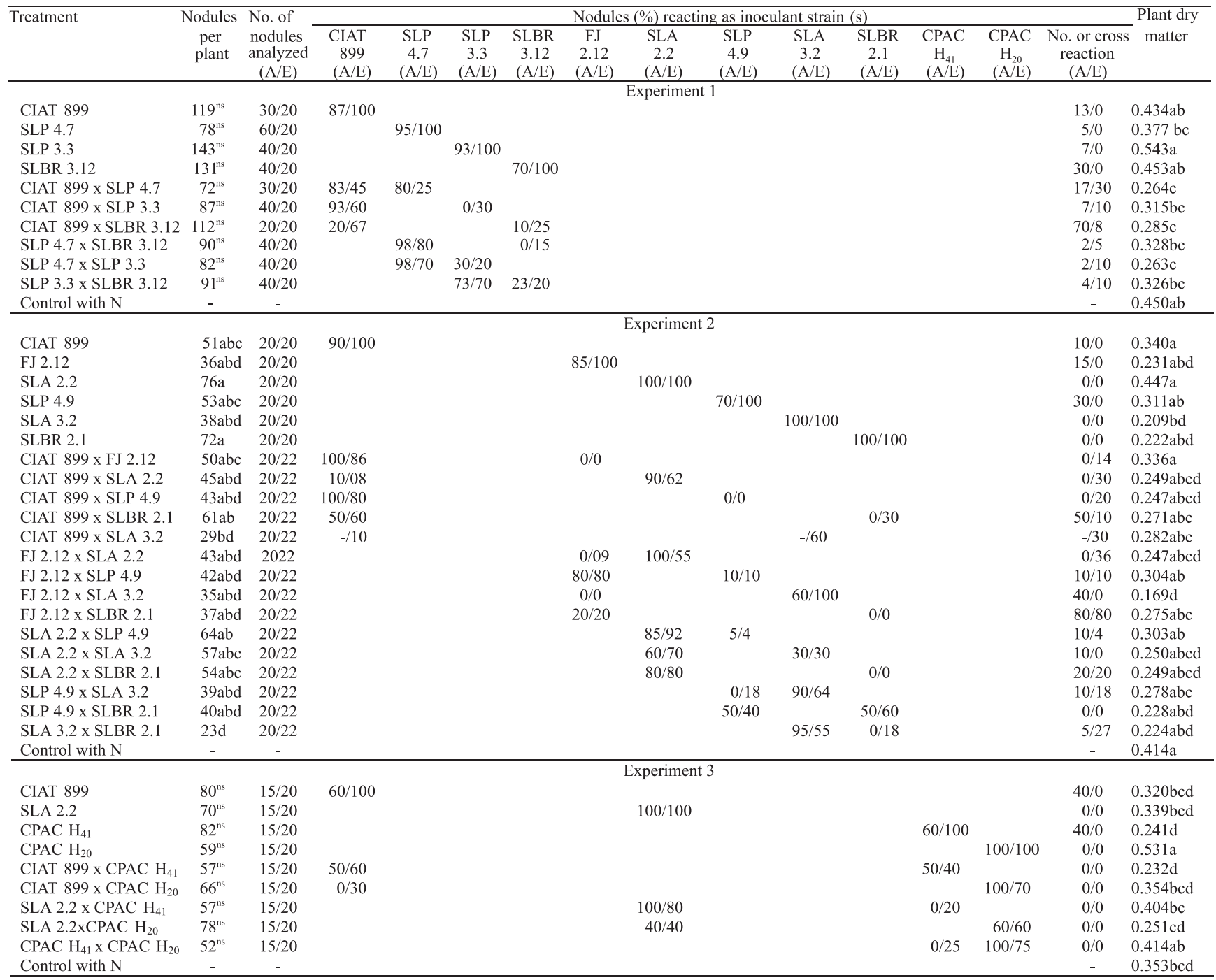

(1) Means followed by the same letter in the column did not differ significantly at 5\% of probability by the Duncan test; CV: 46,6 and 30,4\% (Experiment 1), 42,3 and 26,6\% (Experiment 2), 44,4 and 29,5\% (Experiment 3), for nodules per plant and plant dry matter, respectively. ${ }^{\text {ns Nonsignificant. }}$ 


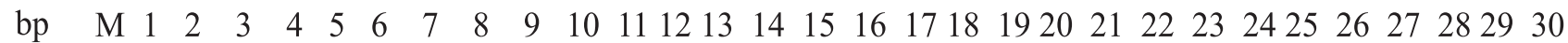

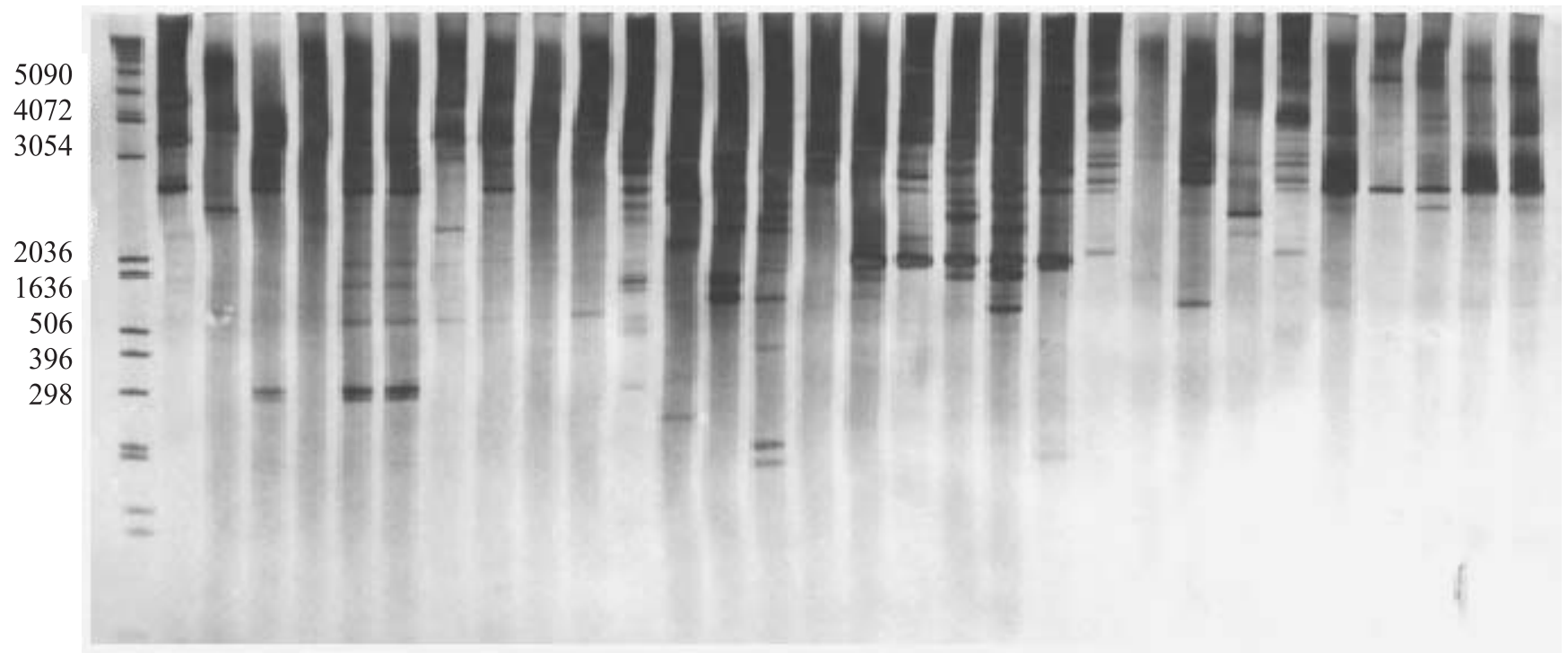

Figure 1. Amplification example of genomic DNA of Rhizobium strains from bean nodules (cultivar Diamante Negro) inoculated with SLA 2.2 and CPAC $\mathrm{H}_{20}$. M-DNA marker, SLA 2.2 (1-11-21), $\mathrm{CPAC}_{20}$ (2-12-22), strains from nodules formed by coinoculation of SLA 2.2 and $\mathrm{CPAC}_{20}$ using primer OPAA10 (3-4-5-6-7-8-9-10), using primer OPAC10 (13-14-15-16-17-1819-20), and co-inoculation of SLA 2.2 and CPAC $\mathrm{H}_{20}$ with primer OPAC04 (23-24-25-26-27-28-29-30).

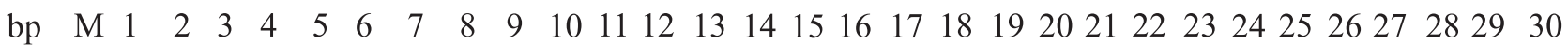

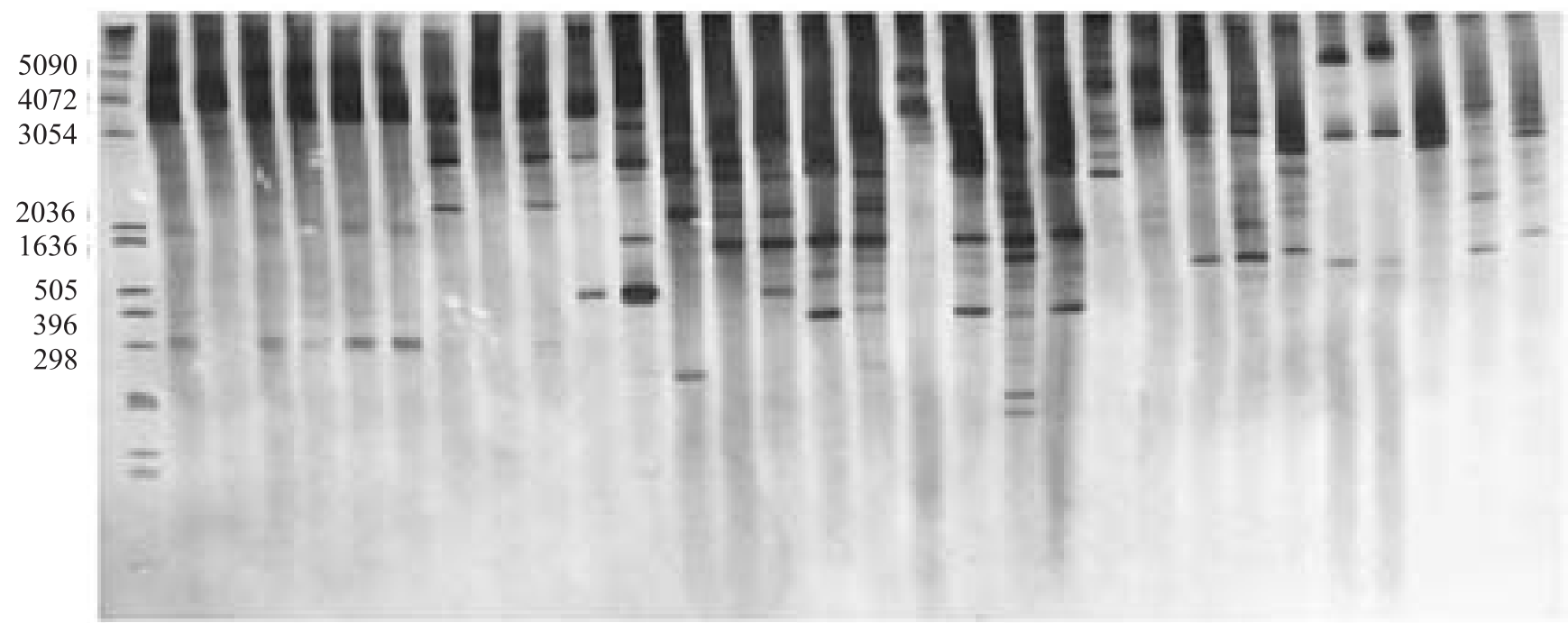

Figure 2. Amplification example of genomic DNA of Rhizobium strains from bean nodules (cultivar Carioca) inoculated with CIAT 899 and $\mathrm{CPAC}_{20}$. M-DNA marker, CIAT 899 (1-11-21), $\mathrm{CPAC}_{20}$ (2-12-22), strains from nodules formed by co-inoculation of CIAT 899 and $\mathrm{CPAC}_{20}$ using primer OPAA10 (3-4-5-6-7-8-9-10), using primer OPAC10 (13-14-15-16-17-18-19-20), and co-inoculation of CIAT 899 and CPAC $\mathrm{H}_{20}$ with OPAC04 (23-24-25-26-27-28-29-30). 
was the most competitive among the strains in both cultivars, not only when inoculated alone (60 to 75\%) but also when co-inoculated with any of the other strains (48 to $87 \%$ ) (Table 2). Although the $\mathrm{CAPC}_{20}$ was very competitive in axenic conditions, in pot culture it showed less competitiveness. When inoculated alone, only $20-30 \%$ of nodule occupancy in cv. Carioca and 30\% in cv. Diamante Negro. When co-inoculated with SLA 2.2 or CIAT 899, this strain showed levels of nodule occupancy between 10 and 20\% in cv. Carioca and it was not detected in cv. Diamante Negro. These results evidence that the competitiveness of each Rhizobium strain depends not only on its genetic intrinsic characteristics for development of this ability but it is also influenced by environmental factors and the genotype of the host legume (Brutti et al., 1999). The CIAT 899 strain was detected in nodules of both cultivars between 25 to $35 \%$, when inoculated alone. When coinoculated with other strains, the result was variable. It was more competitive in relation to $\mathrm{CPAC}_{20}(40-50 \%)$ and less competitive than SLA 2.2. As shown in Table 3, there were positive effects in inoculation of both cultivars, estimated by plant dry weight. However, this effect was apparently more accentuated in cv. Carioca, where dry weight production was higher in treatments in which plant growth was symbiosis dependent.

Several studies observed nodule occupancy range with host cultivars (Handley et al., 1998). In beans, Buttery et al. (1997) showed significantly different effects between cultivars and Rhizobium strains in plant growth, nitrogen content and seed production. Other studies also reported the ability of a cultivar to select a particular strain and emphasized that this preference could be of major significance in resolving strain competition problem in Phaseolus vulgaris.

Although the plants that received mineral $\mathrm{N}$ fertilizer produced significantly greater shoot dry weights and $\mathrm{N}$ content, some treatments, especially with inoculation with SLA 2.2, showed significant production improvement. This effect in CIAT 899 inoculation was smaller, especially with "Diamante Negro". No effect was observed with $\mathrm{CPAC} \mathrm{H}_{20}$ strain inoculation, whose treatment was equivalent statistically to control without inoculation in both cultivars. The nodules number did not show statistical differences at $5 \%$ of probability.

Under field conditions, in site A (Table 4), the SLA 2.2 strain confirmed its higher competitiveness observed in previous experiments through the highest nodule occupancy, both when inoculated alone (68 to $84 \%$ ) or when co-inoculated with other strains (50 to 87\%), identified by RAPD. The CIAT 899 strain also presented high levels of nodule occupancy when inoculated alone (60 to $70 \%$ ) or when co-inoculated with PRF 81 strain (70 to 83\%). However, when coinoculated with SLA 2.2, it showed low levels of nodule occupancy (25 to 32\%). PRF 81 was the least competitive strain. In this site, most yield plots were inoculated with SLA 2.2 (Table 5). In these treatments, plant dry weight, seed yield and plant nitrogen were equivalent or superior to that of treatments with $20 \mathrm{~kg} \mathrm{ha}^{-1}$ of N mineral. The CIAT 899 strain inoculation showed lower yield than that of SLA 2.2, close to the treatments with $20 \mathrm{~kg} \mathrm{ha}^{-1}$ of $\mathrm{N}$ mineral application, however, higher than the control without inoculation. Effect of PRF 81 inoculation was not observed. This treatment was statistically equivalent to control without inoculation.

In the second experiment, same site, including two more levels of mineral N, SLA 2.2 confirmed its highest competitiveness either alone or inoculated with CIAT 899 (Table 6). The CIAT 899 strain increased its nodule occupancy level in relation to the first experiment. The PRF 81 showed again the least nodule occupancy with all primers used in its identification. In treatments without inoculation with 20 and $40 \mathrm{~kg} \mathrm{ha}^{-1}$ of $\mathrm{N}$, nodule occupancy of 0 to $25 \%$ were detected, according to the primer, especially of SLA 2.2 and CIAT 899 (Table 6).

Table 2. Competitive occupancy of bean nodules by Rhizobium strains, determined by RAPD in two cultivars, Carioca and Diamante Negro, in pot culture under greenhouse conditions ${ }^{(1)}$.

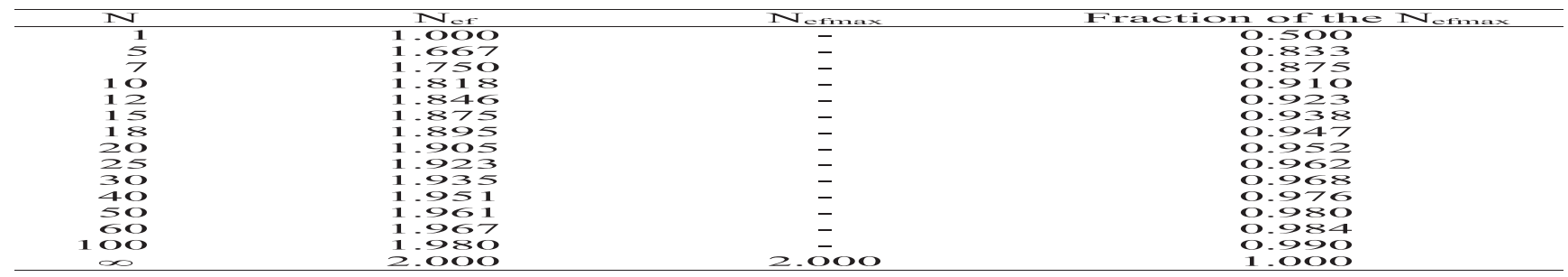

${ }^{(1)} \mathrm{N}$ : number of nodules analyzed; X: other Rhizobium strains. 
This fact is common in field experiments due to the complexity of avoiding contamination among the plots, especially in reinoculated areas (Table 6). In this study (Table 5), reinoculations with SLA 2.2 and CIAT 899 contributed for yields comparable to those obtained with 20 to $40 \mathrm{~kg} \mathrm{ha}^{-1}$ of $\mathrm{N}$. The dry weight and total $\mathrm{N}$ in treatments inoculated with these strains were comparable with treatments with 40 to $60 \mathrm{~kg} \mathrm{ha}^{-1}$ of $\mathrm{N}$. For PRF 81 strain, no response was observed after reinoculation. These results, especially those with CIAT 899, apparently indicate that the reinoculation may be important to help the establishment of some strains in the soil, resulting in increases in nodulation and yield

Table 3. Nitrogen fixation, dry matter and nodulation of bean plants of cultivars Carioca and Diamante Negro inoculated with Rhizobium strains in pot culture under greenhouse conditions ${ }^{(1)}$.

\begin{tabular}{|c|c|c|c|}
\hline Treatment & $\begin{array}{l}\text { Plant dry matter } \\
\quad\left(\text { g plant }^{-1}\right)\end{array}$ & $\begin{array}{l}\text { Number of } \\
\text { nodules }\end{array}$ & $\begin{array}{l}\text { Plant total N } \\
\left(\mathrm{mg} \mathrm{plant}^{-1}\right)\end{array}$ \\
\hline & \multicolumn{3}{|c|}{ Carioca } \\
\hline Mineral N & $2.39 \mathrm{a}$ & - & $94.6 \mathrm{a}$ \\
\hline Control without $\mathrm{N}$ & $1.26 \mathrm{~d}$ & $55^{\mathrm{ns}}$ & $36.3 \mathrm{~d}$ \\
\hline CIAT 899 & $1.48 \mathrm{bc}$ & $92^{\text {ns }}$ & $52.5 \mathrm{bc}$ \\
\hline SLA 2.2 & $1.73 \mathrm{ab}$ & $76^{\mathrm{ns}}$ & $63.1 \mathrm{~b}$ \\
\hline $\mathrm{CPAC} \mathrm{H}_{20}$ & $1.30 \mathrm{bcd}$ & $65^{\mathrm{ns}}$ & $45.1 \mathrm{~cd}$ \\
\hline CIAT 899 x SLA 2.2 & $1.58 \mathrm{abc}$ & $71^{\text {ns }}$ & $57.0 \mathrm{bc}$ \\
\hline CIAT $899 \times$ CPAC $\mathrm{H}_{20}$ & $1.63 \mathrm{ab}$ & $98^{\mathrm{ns}}$ & $59.0 \mathrm{bc}$ \\
\hline SLA $2.2 \times \mathrm{CPAC}_{20}$ & $1.61 \mathrm{ab}$ & $77^{\text {ns }}$ & $63.6 \mathrm{~b}$ \\
\hline \multirow[t]{2}{*}{$\mathrm{CV}(\%)$} & 13.9 & 30.9 & 2.6 \\
\hline & \multicolumn{3}{|c|}{ Diamante Negro } \\
\hline Mineral N & $2.34 \mathrm{a}$ & - & $98.2 \mathrm{a}$ \\
\hline Control without $\mathrm{N}$ & $0.98 \mathrm{bc}$ & $67^{\mathrm{ns}}$ & $30.6 \mathrm{~d}$ \\
\hline CIAT 899 & $1.25 \mathrm{abc}$ & $65^{\mathrm{ns}}$ & $48.1 \mathrm{bc}$ \\
\hline SLA 2.2 & $1.33 \mathrm{abc}$ & $103^{\text {ns }}$ & $52.3 b$ \\
\hline $\mathrm{CPAC} \mathrm{H}_{20}$ & $0.81 \mathrm{~cd}$ & $80^{\text {ns }}$ & $28.3 \mathrm{~d}$ \\
\hline CIAT 899 x SLA 2.2 & $1.23 \mathrm{abc}$ & $56^{\mathrm{ns}}$ & $40.6 \mathrm{c}$ \\
\hline CIAT $899 \times$ CPAC $\mathrm{H}_{20}$ & $1.40 \mathrm{ab}$ & $48^{\mathrm{ns}}$ & $46.8 \mathrm{bc}$ \\
\hline SLA $2.2 \times$ CPAC $\mathrm{H}_{20}$ & $1.56 \mathrm{ab}$ & $79^{\mathrm{ns}}$ & $51.3 \mathrm{~b}$ \\
\hline CV (\%) & 17.2 & 34.3 & 7.0 \\
\hline
\end{tabular}

(1) Means followed by the same letter in each column did not differ

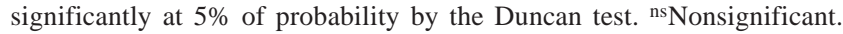

(Vlassak et al., 1996). In site B, yield was higher in all treatments including the control, not inoculated (Table 5), probably due to the high fertility in this area, especially in phosphorus and organic matter contents. However, the inoculation response, in this site, is not so evident, as opposed to results with this soil in greenhouse experiments.

Many authors have pointed the limitations of the extrapolation on greenhouse results for the field, explaining that controlled conditions, inoculum proximity and multiplication can favor the inoculation response (Somasegaran \& Bohlool, 1990). The range of soil organic matter can affect the inoculation. Brutti et al. (1999) confirm this effect in competitiveness experiments, in different soil with Bradyrhizobium japonicum, for soybean nodulation. On the other hand, results observed also indicated the influence of the indigenous rhizobial populations.

Site B, previously cultivated with different legumes, including beans, showed high rhizobial number ( $10^{3}$ to $10^{5}$ viable cells per g of soil). Many authors (Sessitsch et al., 2002) cite that the presence of well established rhizobial population is one of the principal limitations for inoculation success. This fact is more relevant in Brazilian soils, where naturalized bean rhizobial population is considered very high (Hungria et al., 1997). In sites with lower rhizobial population, especially due to the absence of host legume (Sá, 2001) and lower levels of fertility, as probably occurred in site $\mathrm{A}$, the inoculation response is more evident. In this site, the SLA 2.2 strain showed more competitiveness and was the only one to contribute significantly for plant yield. In subsequent experiments with reinoculation, CIAT 899 strain reached similar results. This supremacy of SLA 2.2 strain may be associated with

Table 4. Competitive occupancy of bean nodules by Rhizobium strains by RAPD in field (first experiment, site A) ${ }^{(1)}$.

\begin{tabular}{|c|c|c|c|c|c|c|c|c|c|c|c|c|}
\hline \multirow[t]{2}{*}{ Treatment } & \multicolumn{4}{|c|}{ Primer OPAC03 } & \multicolumn{4}{|c|}{ Primer OPAE10 } & \multicolumn{4}{|c|}{ Primer OPAC10 } \\
\hline & CIAT 899 & SLA 2.2 & PRF 81 & $\mathrm{X}$ & CIAT 899 & SLA 2.2 & PRF 81 & $\mathrm{X}$ & CIAT 899 & SLA 2.2 & PRF 81 & $\mathrm{X}$ \\
\hline & & & & & Nodules (\%) & s original & ingerprin & strai & & & & \\
\hline CIAT 899 & 60 & & & 40 & 70 & & & 30 & 70 & & & 30 \\
\hline SLA 2.2 & & 74 & & 26 & & 84 & & 16 & & 68 & & 32 \\
\hline PRF 81 & & & 15 & 85 & & & 23 & 77 & & & 35 & 65 \\
\hline CIAT 899 x SLA 2.2 & 25 & 50 & & 25 & 25 & 50 & & 25 & 32 & 68 & & 0 \\
\hline CIAT 899 x PRF 81 & 83 & & 17 & 0 & 70 & & 30 & 0 & 76 & & 13 & 11 \\
\hline SLA $2.2 \times$ PRF 81 & & 87 & 13 & 0 & & 80 & 20 & 0 & & 87 & 6 & 7 \\
\hline
\end{tabular}

(1)Number of nodules analyzed for each treatment: 30; X: other Rhizobium strains. 
Table 5. Dry matter (g plant $\left.{ }^{-1}\right)$, grain yield $\left(\mathrm{kg} \mathrm{ha}^{-1}\right)$ and total $\mathrm{N}\left(\mathrm{g}\right.$ plant ${ }^{-1}$ ) of bean plants inoculated with Rhizobium strains in two sites of Cerrado ${ }^{(1)}$.

\begin{tabular}{|c|c|c|c|c|c|c|c|c|c|}
\hline \multirow[t]{2}{*}{ Treatment } & \multicolumn{3}{|c|}{$1^{\text {st }}$ experiment, site $\mathrm{A}$} & \multicolumn{3}{|c|}{$2^{\text {nd }}$ experiment, site $\mathrm{A}$} & \multicolumn{3}{|c|}{ Site B } \\
\hline & $\begin{array}{c}\text { Plant dry } \\
\text { matter }\end{array}$ & $\begin{array}{l}\text { Grain } \\
\text { yield }\end{array}$ & $\begin{array}{c}\text { Total } \\
\mathrm{N}\end{array}$ & $\begin{array}{l}\text { Plant dry } \\
\text { matter }\end{array}$ & $\begin{array}{l}\text { Grain } \\
\text { yield }\end{array}$ & $\begin{array}{c}\text { Total } \\
\mathrm{N}\end{array}$ & $\begin{array}{c}\text { Plant dry } \\
\text { matter }\end{array}$ & $\begin{array}{l}\text { Grain } \\
\text { yield }\end{array}$ & $\begin{array}{c}\text { Total } \\
\mathrm{N}\end{array}$ \\
\hline SLA 2.2 & $30.1 \mathrm{a}$ & $2,129.6 \mathrm{a}$ & $1.02 \mathrm{a}$ & $54.6 \mathrm{a}$ & $1,625.0 \mathrm{bc}$ & $2.02 \mathrm{~b}$ & $30.0 \mathrm{ab}$ & $3,142.0 \mathrm{abc}$ & $1.01 \mathrm{bc}$ \\
\hline CIAT 899 & $23.1 \mathrm{bc}$ & $1,234.0 \mathrm{~cd}$ & $0.71 \mathrm{de}$ & $51.0 \mathrm{a}$ & $1,787.3 \mathrm{bc}$ & $1.75 \mathrm{c}$ & $36.5 \mathrm{ab}$ & $3,399.0 \mathrm{ab}$ & $1.14 \mathrm{~b}$ \\
\hline PRF 81 & $18.6 \mathrm{c}$ & $1,182.0 \mathrm{~cd}$ & $0.54 \mathrm{f}$ & $11.7 \mathrm{c}$ & $1,087.3 \mathrm{f}$ & $0.39 \mathrm{~g}$ & $29.2 \mathrm{ab}$ & $2,384.0 \mathrm{c}$ & $0.87 \mathrm{~cd}$ \\
\hline SLA $2.2 \times$ CIAT 899 & $26.7 \mathrm{ab}$ & $1,731.0 \mathrm{ab}$ & $0.88 \mathrm{bc}$ & $39.8 \mathrm{ab}$ & $1,537.3 \mathrm{bcd}$ & $1.26 \mathrm{~d}$ & $25.0 \mathrm{~b}$ & $3,117.0 \mathrm{abc}$ & $0.70 \mathrm{e}$ \\
\hline SLA 2.2 x PRF 81 & $26.6 \mathrm{ab}$ & $1,582.6 \mathrm{bc}$ & $0.79 \mathrm{~cd}$ & $34.0 \mathrm{ab}$ & $1,266.6 \mathrm{def}$ & $1.02 \mathrm{e}$ & $27.8 \mathrm{ab}$ & $2,992.0 \mathrm{bc}$ & $0.82 \mathrm{~d}$ \\
\hline CIAT 899 x PRF 81 & $26.5 \mathrm{ab}$ & $1,530.0 \mathrm{bcd}$ & $0.80 \mathrm{bcd}$ & $40.5 \mathrm{ab}$ & $1,166.6 \mathrm{ef}$ & $1.31 \mathrm{~d}$ & $29.7 \mathrm{ab}$ & $2,612.0 \mathrm{bc}$ & $0.88 \mathrm{~cd}$ \\
\hline Control without $\mathrm{N}$ & $20.5 \mathrm{c}$ & $1,134.0 \mathrm{~d}$ & $0.68 \mathrm{e}$ & $14.0 \mathrm{c}$ & $1,400.0 \mathrm{cdef}$ & $0.41 \mathrm{~g}$ & $27.1 \mathrm{ab}$ & $2,606.0 \mathrm{bc}$ & $0.81 \mathrm{~d}$ \\
\hline $20 \mathrm{~kg} \mathrm{ha}^{-1} \mathrm{~N}$ & $25.9 \mathrm{ab}$ & $2,103.0 \mathrm{a}$ & $0.89 \mathrm{~b}$ & $28.7 \mathrm{ab}$ & $1,816.6 \mathrm{bc}$ & $0.93 \mathrm{ef}$ & $33.6 \mathrm{ab}$ & $3,044.6 \mathrm{abc}$ & $1.04 \mathrm{bc}$ \\
\hline $40 \mathrm{~kg} \mathrm{ha}^{-1} \mathrm{~N}$ & - & - & - & $38.2 \mathrm{~b}$ & $2,133.3 \mathrm{~b}$ & $1.31 \mathrm{~d}$ & $44.3 \mathrm{a}$ & $4,028.0 \mathrm{a}$ & $1.19 \mathrm{~b}$ \\
\hline $60 \mathrm{~kg} \mathrm{ha}^{-1} \mathrm{~N}$ & - & - & - & $58.6 \mathrm{a}$ & $2,562.3 \mathrm{a}$ & $2.13 \mathrm{a}$ & $45.7 \mathrm{a}$ & $4,128.3 \mathrm{a}$ & $1.55 \mathrm{a}$ \\
\hline CV (\%) & 7.1 & 9.1 & 6.2 & 48.2 & 8.8 & 3.8 & 19.3 & 11.3 & 5.6 \\
\hline
\end{tabular}

(1) Means followed by the same letter in each column did not differ significantly at $5 \%$ of probability by the Duncan test.

Table 6. Competitive occupancy of bean nodules by Rhizobium strains by RAPD in field (second experiment, site A).

\begin{tabular}{|c|c|c|c|c|c|c|c|c|c|c|c|c|c|}
\hline \multirow[t]{2}{*}{ Treatment } & \multirow{2}{*}{$\begin{array}{l}\text { Nodules } \\
\text { analyzed }\end{array}$} & \multicolumn{4}{|c|}{ Primer OPAC03 } & \multicolumn{4}{|c|}{ Primer OPAE10 } & \multicolumn{4}{|c|}{ Primer OPAC10 } \\
\hline & & CIAT 899 & SLA 2.2 & PRF 81 & $\mathrm{X}^{(1)}$ & CIAT 899 & SLA 2.2 & PRF 81 & $\mathrm{X}$ & CIAT 899 & SLA 2.2 & PRF 81 & $\mathrm{X}$ \\
\hline & \multicolumn{13}{|c|}{ Nodules (\%) as original fingerprint strain } \\
\hline CIAT 899 & 27 & 72 & & & 28 & 81 & & & 19 & 65 & & & 35 \\
\hline SLA 2.2 & 28 & & 60 & & 40 & & 83 & & 17 & & 67 & & 33 \\
\hline PRF 81 & 22 & & & 0 & 100 & & & 33 & 67 & & & 33 & 67 \\
\hline CIAT 899 x SLA 2.2 & 25 & 20 & 55 & & 25 & 38 & 62 & & 0 & 23 & 70 & & 7 \\
\hline Control without $\mathrm{N}$ & 25 & 25 & 5 & 0 & 70 & 0 & 0 & 5 & 95 & 7 & 25 & 5 & 63 \\
\hline Mineral $\mathrm{N}\left(20\right.$ and $\left.40 \mathrm{~kg} \mathrm{ha}^{-1}\right)$ & 38 & 0 & 0 & 0 & 100 & 3 & 5 & 0 & 92 & 15 & 10 & 0 & 75 \\
\hline
\end{tabular}

${ }^{(1)} \mathrm{X}$ : other Rhizobium strains.

the fact that this strain comes from this soil region and the good performance of the commercial strain CIAT 899, after reinoculation, confirms its competitiveness power in some conditions. In opposition, PRF 81 strain, which comes from other region and is regarded as competitive and efficient in some soils, especially from the south region (Hungria et al., 1997), was not successful in this “cerrado" soil conditions.

The influence of one strain on the other, in a mixed inoculum, was observed together with the ability of individual competitiveness of each strain influenced by soil conditions and its interaction with rhizosphere and naturalized rhizobial population. In these studies, the inoculation response was more evident when the strain was inoculated alone. Since the Brazilian law requires the presence of at least two strains, it is important to co-select effective and competitive as well as compatible rhizobial for multistrain inoculant formulations.

\section{Conclusions}

1. Rhizobium strain identification in soil is only suitable by RAPD method; agglutination and Elisa assays are only effective under axenic conditions.

2. SLA 2.2 and CIAT 899 are competitive strains for bean inoculation in some Cerrado soil conditions, especially represented by low levels of fertility and reduced rhizobial population.

3. Rhizobium strain competitiveness, besides its interaction with soil conditions, host, rhizosphere and native population, may be also influenced by the presence of other strain in the same inoculant.

\section{Acknowledgements}

To Dr. Ieda Mendes, of Embrapa Cerrados, for her assistance in the inoculants preparation; to Fapemig, for supporting the work. 


\section{References}

AHMAD, M.H.; EAGLESHAN, A.R.J.; HASSOUNA, S. Examining serological diversity of "Cowpea" rhizobia by the ELISA technique. Archives of Microbiology, v.130, p.281-287, 1981.

AMARGER, N.; MACHERET, V.; LAGUERRE, G. Rhizobium gallicum sp. nov. and Rhizobium giardinii sp. nov., from Phaseolus vulgaris nodules. International Journal of Systematic Bacteriology, v.47, p.996-1006, 1997.

BROWN, P.D.; AHMAD, M.H. Competitive interaction among strains of Rhizobium leguminosarum bv. phaseoli in the nodulation of kidney beans (Phaseolus vulgaris L.). Biology and Fertility of Soils, v.21, p.7-9, 1996.

BRUTTI, L.; PIANTANIDA, N.; LJUNGGREN, H.; BERGGREN, I.; MARTENSSON, A. Competition between strains of Bradyrhizobium japonicum for nodulation of soybeans in Argentine arable soils. Applied Soil Ecology, v.12, p.1-6, 1999.

BUTTERY, B.R.; PARK, S.J.; BERKUM, P. van. Effects of common bean (Phaseolus vulgaris L.) cultivar and Rhizobium strain on plant growth, seed yield and nitrogen content. Canadian Journal of Plant Science, v.77, p.347-351, 1997.

CHATEL, D.L.; GREENWOOD, R.M.; PARKER, C.A. Saprophytic competence as an important character in the selection of Rhizobium for inoculation. In: INTERNATIONAL CONGRESS OF SOIL SCIENCE, 9., 1968, New York. Anais. New York: Elsevier, 1968. v.2, p.65-73.

HANDLEY, B.A.; HEDGES, A.J.; BERINGER, J.E. Importance of host plants for detecting the population diversity of Rhizobium leguminosarum biovar viciae in soil. Soil Biology and Biochemistry, v.30, p.241-249, 1998.

HUNGRIA, M.; VARGAS, M.A.T.; ARAÚJO, R.S. Fixação biológica do nitrogênio em feijoeiro. In: VARGAS, M.A.T.; HUNGRIA, M. (Ed.). Biologia dos solos dos Cerrados. Planaltina, DF: Embrapa-CPAC, 1997. p.189-295.

JORDAN, D.C. Rhizobiaceae. In: KRIEG, N.R.; HOLT, J.G. (Ed.). Bergey's manual of systematic bacteriology. Baltimore: Williams \& Wilkins, 1984. v.1, p.235-244.

KHAN, M.S.; ZAIDI, A.; LAKHCHAURA, B.D. Nodule occupancy determination and Rhizobium strain quantification by immunoblot assay. Indian Journal of Experimental Biology, v.37, p.813-817, 1999.

MARTINEZ-ROMERO, E.; SEGOVIA, L.; MERCANTE, F.M.; FRANCO, A.A.; GRAHAM, P.; PARDO, M.A. Rhizobium tropici, a novel species nodulating Phaseolus vulgaris L. beans and Leucaena sp. trees. International Journal of Systematic Bacteriology, v.41, p.417-426, 1991.

PEREIRA, J.C.; VIDOR, C.; LOVATO, P.E.; PENTEADO, A. de F. Eficiência e capacidade competitiva de estirpes de Rhizobium leguminosarum bv. phaseoli em feijão. Pesquisa Agropecuária Brasileira, v.26, p.1073-1080, 1991.

PINTO, P.P.; KATTAH, L.S.; SÁ, N.M.H. de. Termotolerância e eficiência em fixar $\mathrm{N}_{2}$, de estirpes de Rhizobium nativas, isoladas de áreas de cultivo do feijoeiro nos Cerrados. In: CONGRESSO BRASILEIRO DE CIÊNCIA DO SOLO, 25., 1995, Viçosa. Anais. Viçosa: [s. n.], 1995. v.1, p.509-511.

PROVOROV, N.A.; SAIMNAZAROV, U.B.; TANRIVERDIEV, T.A.; SIMAROV, B.V. The contributions of plant and bacteria genotypes in the growth and nitrogen accumulation of the inoculated alfalfa. Plant and Soil, v.164, p.213-219, 1994.

SÁ, N.M.H. de. Seasonal dynamic of Native rhizobial populations associated with Arachis pintoi in Cerrado soils. Pasturas Tropicales, v.23, p.29-31, 2001.

SÁ, N.M.H. de; KATTAH, L. de S.; SELDIN, L.; VASCONCELOS, M.J.V.; PAIVA, E. Genomic heterogeneity within bean nodulating Rhizobium strains isolated from Cerrado soils. Soil Biology and Biochemistry, v.29, p.1011-1014, 1997.

SANTOS, F.R.; PENA, S.D.J.; EPPLEN, J.T. Genetic and population study of a Y-linked tetranucleotide repeat DNA polymorphism with a simple non-isotopic technique. Human Genetics, v.90, p.655656, 1993.

SEGOVIA, L.; YOUNG, J.P.; MARTINEZ-ROMERO, E. Reclassification of American Rhizobium leguminosarum biovar phaseoli type I strains as Rhizobium etli sp. nov. International Journal of Systematic Bacteriology, v.43, p.374-377, 1993.

SESSITSCH, A.; HOWIESON, J.G.; PERRET, X.; ANTOUN, H.; MARTINEZ-ROMERO, E. Advances in Rhizobium research. Critical Reviews in Plant Sciences, v.21, p.323-378, 2002.

SOMASEGARAN, P.; BOHLOOL, B.B. Single-strain versus multistrain inoculation: effect of soil mineral $\mathrm{N}$ availability on rhizobial strain effectiveness and competition for nodulation on chickpea, soybean, and dry bean. Applied and Environmental Microbiology, v.56, p.3298-3303, 1990.

SOMASEGARAN, P.; HOBEN, H.J. Methods in legumeRhizobium technology. Hawai: Niftal Project; Mircen, 1985. $367 \mathrm{p}$.

TEDESCO, M.J. Métodos de análise de nitrogênio total, amônia, nitrito e nitrato em solos e tecido vegetal. Porto Alegre: Faculdade de Agronomia; Departamento de Solos, 1978. p.19. (Informativo interno, 1).

VINCENT, J.M. A manual for the practical study at root-nodule bacteria. Oxford, Blackwell, 1970. 164p.

VLASSAK, K.; VANDERLEYDEN, J.; FRANCO, A. Competition and persistence of Rhizobium tropici and Rhizobium etli in tropical soil during successive bean (Phaseolus vulgaris L.) cultures. Biology and Fertility of Soils, v.21, p.61-68, 1996. 